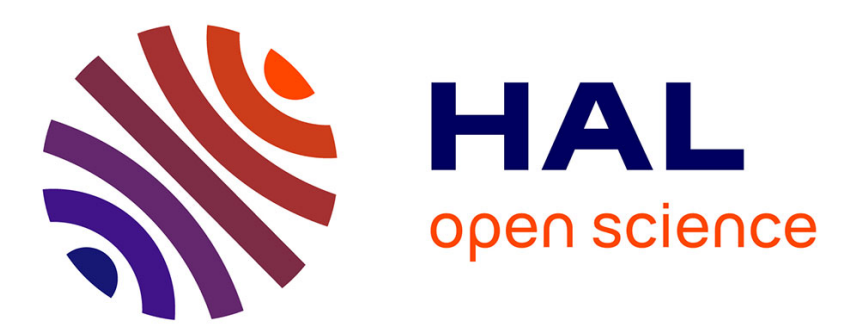

\title{
Oceanic phytoplankton, atmospheric aerosol and Raman scattering impacts on space-based ultraviolet radiance measurements
}

\author{
R.-M. Hu, R. S. Sokhi
}

\section{- To cite this version:}

R.-M. Hu, R. S. Sokhi. Oceanic phytoplankton, atmospheric aerosol and Raman scattering impacts on space-based ultraviolet radiance measurements. Atmospheric Chemistry and Physics Discussions, 2007, 7 (5), pp.14351-14367. hal-00303125

\section{HAL Id: hal-00303125 \\ https://hal.science/hal-00303125}

Submitted on 9 Oct 2007

HAL is a multi-disciplinary open access archive for the deposit and dissemination of scientific research documents, whether they are published or not. The documents may come from teaching and research institutions in France or abroad, or from public or private research centers.
L'archive ouverte pluridisciplinaire HAL, est destinée au dépôt et à la diffusion de documents scientifiques de niveau recherche, publiés ou non, émanant des établissements d'enseignement et de recherche français ou étrangers, des laboratoires publics ou privés. 


\section{Oceanic phytoplankton, atmospheric aerosol and Raman scattering impacts on space-based ultraviolet radiance measurements}

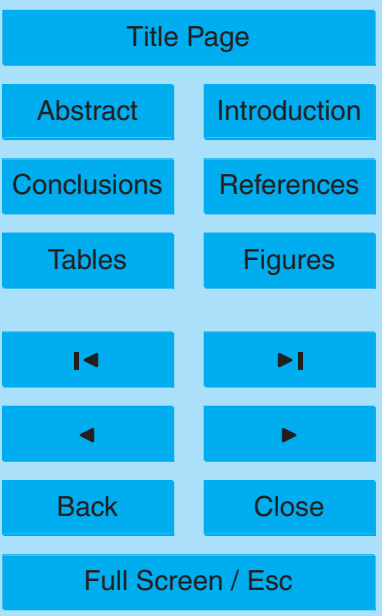

\section{R.-M. Hu and R. S. Sokhi}

Centre for Atmospheric and Instrumentation Research (CAIR), University of Hertfordshire, College Lane, Hatfield, Herts AL109AB, UK

Received: 31 July 2007 - Accepted: 29 September 2007 - Published: 9 October 2007

Correspondence to: R.-M. Hu (r.hu@ herts.ac.uk) 


\section{Abstract}

Oceanic phytoplankton can affect in-water and atmospheric radiation fields. In this study, we develop case 1 (without noncovarying particles) and case 2 (including noncovarying particles) waters model including Raman scattering in order to examine the 5 chlorophyll impacts on the Total Ozone Mapping Spectrometer (TOMS) Aerosol Index and aerosol single scattering albedo. The waters model is coupled with a radiation transfer model (VLIDORT) for calculating TOMS Aerosol Index and retrieval of aerosol single scattering albedo. The retrieval is constrained by chlorophyll concentration from Sea-viewing Wide Field-of-view Sensor (SeaWiFS) and Moderate Resolution Imaging SpectroRadiometer (MODIS) data, aerosol optical depth from MODIS, and aerosol vertical profiles from a global chemical transport model (GEOS-CHEM). We find the retrieved aerosol single scattering albedo is strongly influenced by chlorophyll concentration, particularly in the regions of subtropical Atlantic Ocean and Indian Ocean. The maximum deviation between the aerosol single scattering albedo retrieved with and 15 withouout considering chlorophyll can reach 10 percent. Thus, it is important to take account of the phytoplankton impacts on atmospheric remote sensing measurements.

\section{Introduction}

Broadening and depletion of solar Fraunhofer lines, known as the Ring effect (Grainger and Ring, 1962), can make a significant contribution to backscattered ultraviolet radiances measured by satellite instruments (Chance and Spurr, 1997; Vasilkov et al., 2002). Meanwhile, ocean Raman scattering has been observed to influence the spectral scan measurements (Marshall and Smith, 1990; Gordon, 1999). Studies have shown that detailed information of oceanic optical properties relating to phytoplankton is very important to interpret satellite measurements (Gordon et al., 1988; Morel et al., 25 1988; Morel et al., 2002). Such measurements are useful to better understand aerosol formation over ocean. Photochemical degradation of oceanic phytoplankton can fur-
Oceanic impacts on ultraviolet radiance

R.-M. Hu and R. S. Sokhi

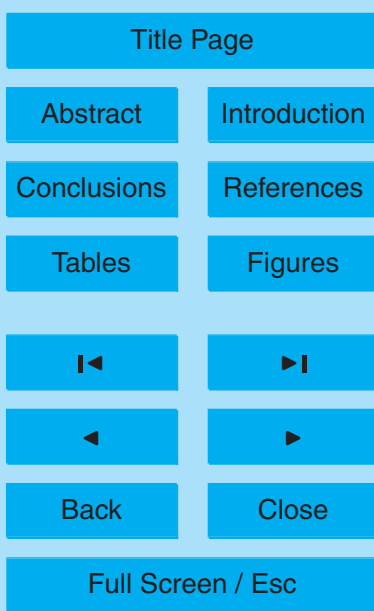

Printer-friendly Version

Interactive Discussion 
ther lead to a decrease in the dimethyl sulphide (DMS) production and hence the reduction of oceanic sulfate aerosols which counteract the warming of the greenhouse effect (Charlson et al., 1987). However, the degradation of phytoplankton pigments associated with ultraviolet radiation flux has been hypothesized to inhibit oceanic carbon 5 sinks and result in more carbon dioxide remaining in the atmosphere (De More et al., 2000).

In remote sensing applications, the backscattered radiance measured by a satellite instrument is sensitive to oceanic surface reflectivity. The seawater Inherent Optical Properties (IOPs) are determined by the absorption and scattering of pure water and 10 dissolved or suspended inorganic and biotic pigments in turbid waters. It has been understood that the constituents in oceanic waters such as pigment chlorophyll-a in phytoplankton could affect the water reflectance significantly and lead to the variability of ocean reflectance in the ultraviolet. Currently, the derivation of ozone and aerosol products from the Total Ozone Mapping Spectrometer (TOMS) is based on minimum 15 Lambert equivalent surface reflectivity (Herman etal., 1997). Therefore, accurate estimation of the ocean reflectivity can improve the retrieval of total ozone column and aerosol from the TOMS and Ozone Monitoring Instrument (OMI) measurements.

Quantifying the ultraviolet radiation effects on the production of phytoplankton pigments and variability of oceanic ultraviolet reflectance requires the accurate estimation of in-water and atmospheric radiation fields. A radiative transfer model can be used to simulate the radiation fields with various water optical properties and solar zenith angles. Our interest here, is to study the inherent optical properties of oceanic waters which affect the ultraviolet radiance measured by satellite sensors and examine the impacts on the TOMS Aerosol Index. Moreover, the influence on our recent developed 25 retrieval of aerosol single scattering albedo (Hu et al., 2007) will be examined. We use the vector discrete ordinate radiative transfer model VLIDORT (with polarization) (Spurr, 2001; Natraj et al., 2007) for calculating the total backscattered radiance. A new parameterization of seawater inherent optical properties as a function of chlorophyll concentration in case 1 water and case 2 water (Vasilikov et al., 2005; Park and

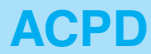

7, 14351-14367, 2007

Oceanic impacts on ultraviolet radiance

R.-M. Hu and R. S. Sokhi

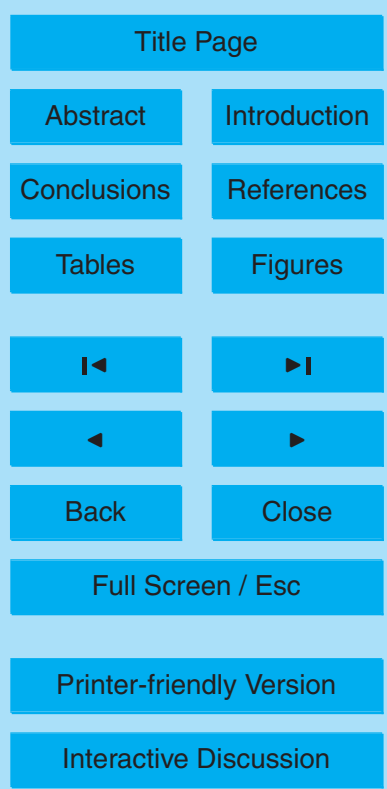


Ruddick, 2005) is extended to the ultraviolet.

\section{Seawater model}

Calculation of seawater inherent optical properties requires the absorption coefficient $A(\lambda)$ and scattering coefficient $B(\lambda)$ ( $\lambda$ is wavelength). The parameterization of the ab5 sorption and scattering model covers realistic waters including case 1 (Chlorophyll, colored dissolved organic matter) and case 2 waters (Chlorophyll, colored dissolved organic matter, and noncovarying particles). The four components, namely, pure seawater, phytoplankton and varying particles, colored dissolved organic matter (CDOM) and noncovarying particles are considered in the seawater model. The total absorption and scattering coefficients are sums of contributions from pure seawater and water constituents as given below:

$A(\lambda)=A_{w}(\lambda)+A_{C}(\lambda)+A_{\mathrm{CDOM}}(\lambda)+A_{N C}(\lambda)$

$B(\lambda)=B_{w}(\lambda)+B_{C}(\lambda)+B_{N C}(\lambda)$

where $A$ is the absorption coefficient $\left(m^{-1}\right)$; B is the scattering coefficient $\left(m^{-1}\right)$; subscripts w, c, CDOM, NC denote pure seawater, phytoplankton and varying particles, colored dissolved organic matter, and noncovarying particles respectively.

The spectral data of $A_{w}$ were taken from Morel and Maritoren (2001), Pope and Fry (1997) and Smith and Baker (1981). As there is no consensus on the pure water absorption in the ultraviolet, we interpolate the values between measurements from Quickenden and Irvin (1980) and Pope and Fry (1997). The values of $A_{C}, A_{\mathrm{CDOM}}$ and $A_{N C}$ are computed as a function of Chlorophyll concentration (Vasilkov et al., 2005; Park and Ruddick, 2005):

$A_{C}(\lambda)=\alpha(\lambda) C^{-\beta(\lambda)}$

$A_{\text {CDOM }}(\lambda)=A_{\text {CDOM }}(440) \exp \left[-S_{\text {CDOM }}(\lambda-440)\right]$

Oceanic impacts on ultraviolet radiance

R.-M. Hu and R. S. Sokhi

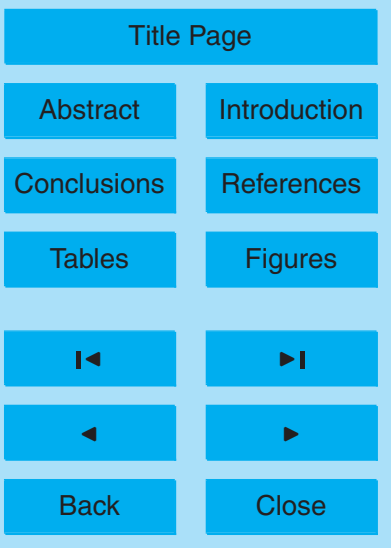

Full Screen / Esc

Printer-friendly Version

Interactive Discussion 
$A_{N C}(\lambda)=A_{N C}(440) \exp \left[-\mathrm{S}_{N C}(\lambda-440)\right]$

where $A_{\mathrm{CDOM}}(440)$ and $A_{N C}(440)$ are absorption coefficients of CDOM and noncovarying particles at $440 \mathrm{~nm} ; \mathrm{C}$ is Chlorophyll concentration and $\alpha, \beta, S_{\mathrm{CDOM}}$ and $S_{N C}$ are coefficients.

5 The scattering coefficients are parameterized as follows:

$B_{C}(\lambda)=B_{c}(550)(550 / \lambda)^{n}$

$B_{N C}(\lambda)=B_{N C}(550)(550 / \lambda)^{n}$

where $B_{C}(550)$ and $B_{N C}(550)$ are scattering coefficients of co-varying and noncovarying particles at $550 \mathrm{~nm}$.

Figure 1 shows that the water reflectivity is strongly related to the chlorophyll concentration in the seawater at TOMS wavelength 331 and $360 \mathrm{~nm}$. For $331 \mathrm{~nm}$, the water reflectivity decreases almost linearly with increasing chlorophyll concentration. However, we find that the water reflectivity does not linearly decrease with increasing chlorophyll concentration for $360 \mathrm{~nm}$. The reason is that the chlorophyll scattering 15 dominates when the chlorophyll concentration is relatively low and absorption dominates when the chlorophyll concentration is high.

\section{Ocean Raman scattering}

In recent years, the trans-spectral scattering (Raman scattering) has been recognized to have an effect on in-water radiative transfer. Along with fluorescence, it transfers energy across the optical spectrum and results in changing the spatial as well as the spectral characteristics of the irradiance field measured by satellite instruments (Marshall and Smith, 1990; Chance and Spurr, 1997; Sathyendranath and Platt, 1998; Gordon, 1999; Vasilkov et al., 2002). We assume that molecular scattering dominates upward scatter, because it is in clear waters that we expect Raman scattering to contribute

Oceanic impacts on ultraviolet radiance

R.-M. Hu and R. S. Sokhi

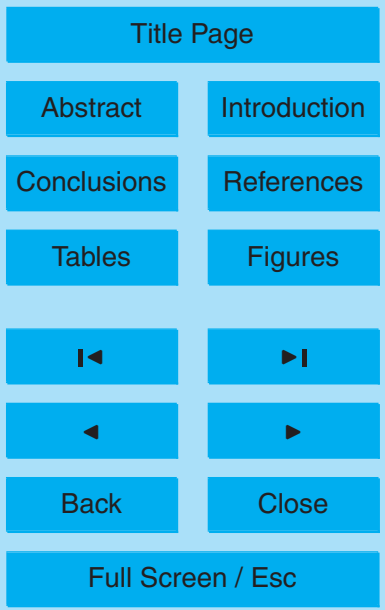

Printer-friendly Version

Interactive Discussion 
most to the total upwelling radiance at the sea surface. To calculate the contribution of Raman scattering to the ocean surface reflectance, we use the formula from Vasilkov et al. (2002):

$R\left(\lambda, \lambda_{e}\right)=B^{R}\left(\lambda_{e}\right) /\left(A\left(\lambda_{e}\right)+B_{b}\left(\lambda_{e}\right)+\left[\mu_{d}\left(\lambda_{e}\right) / \mu_{u}^{R}(\lambda)+B_{b}(\lambda)\right]\right)$

5 Where $\lambda$ and $\lambda_{e}$ are observed wavelength and excitation wavelength. $B^{R}\left(\lambda_{e}\right)$ is the Raman scattering coefficient, $A$ is the absorption coefficient, $B_{b}$ is the backscatter coefficient. $\mu_{d}(=0.75)$ and $\mu_{u}^{R}(=0.5)$ (Sathyendranath and Platt, 1998) are the mean cosines for downwelling irradiance and upwelling Raman scattering irradiance respectively. The Raman-backscattering coefficients are obtained from Marshall and Smith (1990).

10 Figure 2 provides the sensitivity of water reflectivity to chlorophyll concentration when Raman scattering is considered. We find that the Raman scattering increases the water surface reflectivity. Water reflectivity decreases almost linearly with increasing chlorophyll concentration for both TOMS wavelengths. Figure 3 presents the surface reflectivity from Herman et al. (1997) and calculations of the waters model. We find that small differences occur in the regions with high chlorophyll concentration.

\section{TOMS aerosol index and aerosol single scattering albedo}

Figure 4 presents the chlorophyll concentration from SeaWiFS and MODIS data. Turbid waters with high concentration of chlorophyll are present in tropical and high latitudinal oceans, especially in the regions near continents. Clear waters (mode water) with low concentration of chlorophyll, on the other hand, exist in subtropical oceans near $15^{\circ} \mathrm{N}$ during summer and $15^{\circ} \mathrm{S}$ during winter. We use the chlorophyll distribution to calculate its influence on TOMS Aerosol Index which measures the spectral contrast at two different ultraviolet wavelengths 331 and $360 \mathrm{~nm}$ (Herman et al., 1997; Torres et al., 1998).

25 Figure 5 shows the differences between the Aerosol Index calculated using the water reflectivity influenced by chlorophyll and the Lambertian water surface reflectivity.

Oceanic impacts on ultraviolet radiance

R.-M. Hu and R. S. Sokhi

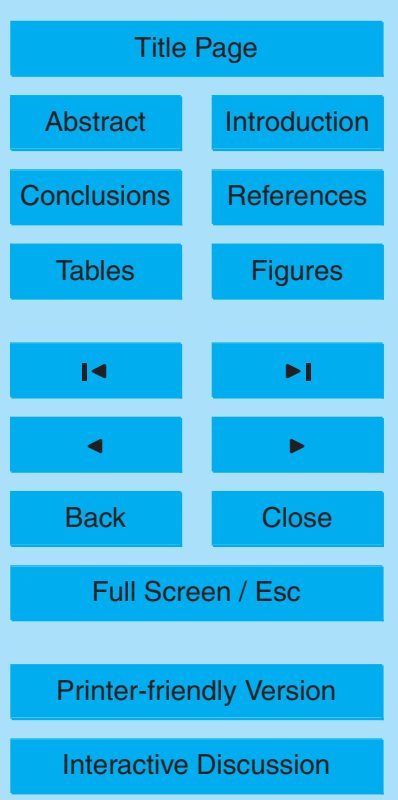


Large differences of TOMS Aerosol Index occur in the subtropical regions during summer. The strong impact of chlorophyll on TOMS Aerosol Index near 0.5 is found in the regions near the east coast of United states and Caribbean sea, west coast of central Africa and east coast of Asia. Large differences of Aerosol Index are also found in the 5 high southern latitudinal oceans during winter.

In order to examine the influence of chlorophyll on our recently developed retrieval of aerosol single scattering albedo ( $\mathrm{Hu}$ et al., 2007), we coupled our waters model with radiative transfer model VLIDORT. The radiative transfer model is used to calculate the local aerosol single scattering albedo to reproduce the TOMS Aerosol Index, 10 when constrained by MODIS aerosol optical depth (King et al., 1999; Kaufman et al., 1997) and by relative vertical profiles from a global chemical transport model (GEOSCHEM) (Martin et al., 2002; Park et al., 2003; Hu et al., 2007). The size distribution of aerosols is assumed to be lognormal with mode radius and standard deviation used in GEOS-CHEM (Martin et al., 2003). We use VLIDORT to produce a look-up table of 15 backscattered radiances $(331 \mathrm{~nm}$ and $360 \mathrm{~nm}$ ) for a variety of atmospheric and surface conditions as a function of all Sun-satellite viewing geometries. The chi-squared minimization method is used to select the best solution (see Hu et al., 2002 for details). The retrieval uncertainty of aerosol properties has been discussed in $\mathrm{Hu}$ et al. (2007). The Angstrom exponent and aerosol optical depth make the largest contribution to the retrieval uncertainty. The retrieval uncertainty is 15 percent.

Figure 6 presents the differences between aerosol single scattering albedo retrieved with and without considering surface water reflectivity influenced by chlorophyll. The resulting differences of retrieved aerosol single scattering albedo strongly occur in turbid waters, for example, tropical and subtropical Atlantic Ocean and Indian Ocean. The largest difference reaches 10 percent near the subtropical Atlantic Ocean and Indian Ocean. The result indicates that the absorbing aerosols may occur in these regions such as Atlantic Ocean and Indian Ocean since the TOMS Aerosol Index is high in these turbid waters. Besides long range transport of absorbing aerosols from near continents to these oceanic regions, the local absorbing aerosol sources from phyto-

Oceanic impacts on ultraviolet radiance

R.-M. Hu and R. S. Sokhi

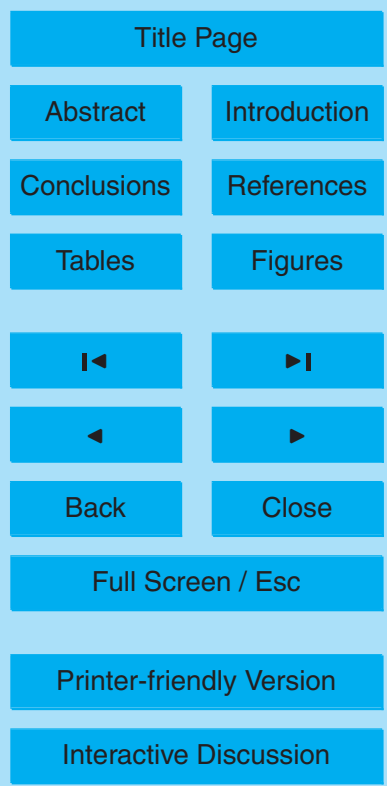




\section{Summary}

Case 1 and case 2 waters model is developed to account for the oceanic phytoplankton effect on the variability of surface seawater reflectivity. The oceanic Raman scattering 5 is considered during radiance calculation. The water reflectivity decreases almost linearly with increasing chlorophyll concentration at TOMS ultraviolet wavelengths. Strong impacts of chlorophyll from SeaWiFS and MODIS data on TOMS Aerosol Index are found in the regions near continents. With constraints of MODIS aerosol optical depth and aerosol vertical profiles generated from GEOS-CHEM model, the retrieved aerosol 10 single scattering albedo from TOMS Aerosol Index is found to be strongly influenced by the seawater chlorophyll concentration. The largest differences between the aerosol single scattering albedo retrieved with and withouout considering chlorophyll can reach 10 percent near the subtropical Atlantic Ocean and Indian Ocean. The positive values of Aerosol Index over ocean besides the clear water absorption indicates that the phytoplankton may not only release a large amount of scattering sulfate aerosols, but also release significant amount of absorbing aerosols (Bishop et al., 2002). The unknown oceanic absorbing aerosols could be composed mostly of biogenic compounds, which could enhance light absorption and accelerate global warming.

Acknowledgements. We would like to thank the scientists and managers for making the TOMS, 20 MODIS and SeaWiFS data publicly available. We are grateful to $R$. Martin for prividing valuble comments, and R. Spurr of RT solutions Inc. for the use of his VILODORT radiative transfer model. This work is supported by the Canadian Foundation for Climate and Atmospheric Science as part of the Multiscale Air Quality Modelling Network and the U.K. Natural Environment Research Council as part of Mesoscale Modelling for Air Pollution Application Network.

25 The GEOS-CHEM model is managed by the Atmospheric Chemistry Modelling group at Harvard University with support from the NASA Atmospheric Chemistry Modelling and Analysis Program.
$7,14351-14367,2007$

Oceanic impacts on ultraviolet radiance

R.-M. Hu and R. S. Sokhi

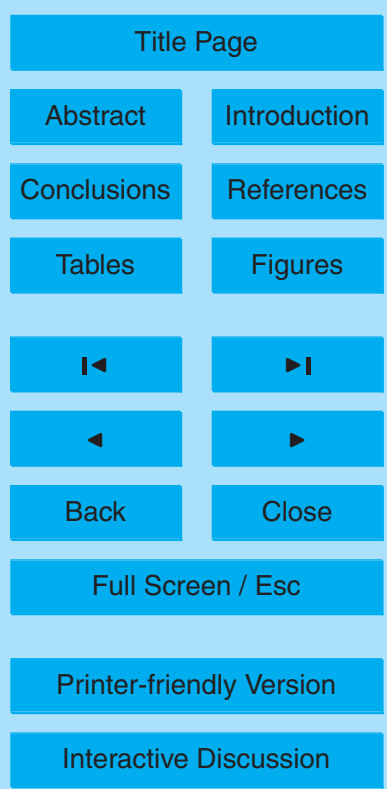

EGU 


\section{References}

Bishop J. K. B., Davis, R. E. and Sherman, J. T.: Robotic observations of dust storm enhancement of carbon biomass in the North Pacific, Science, 298, 817-821, 2002.

Chance, K. V. and Spurr, R. D.: Ring effect studies: Rayleigh scattering, including molecular parameters for rotational Raman scattering, and the Fraunhofer spectrum, Appl. Opt., 36, 5224-5230, 1997.

Charlson, R. J., Lovelock, J. E., Andreae, M. O., and Warren, S. G.: Oceanic phytoplankton, atmospheric sulphur, cloud albedo and climate, Nature, 326, 655-661, 1987.

De More, S., Demers, S., and Vernet, M.: The Effects of UV Radiation in the Marine Environment, Cambridge University, Cambridge, UK, 2000.

Gordon, H. R.: Contribution of Raman scattering to water-leaving radiance: a reexamination, Appl. Opt., 38, 3166-3174, 1999.

Grainger, J. F. and Ring, J.: Anomalous Fraunhofer line profiles, Nature, 193, 762, 1962.

Herman, J. R., Bhartia, P. K., Torres, O., Hsu, C., Seftor, C., and Celarier, E.: Global distribution of ultraviolet-absorbing aerosols from Nimbus 7-TOMS data, J. Geophys. Res., 102, 16911$16922,1997$.

Hu, R.-M., Martin, R. V., and Fairlie, T. D.: Global retrieval of columnar aerosol single scattering albedo from space-based observations, J. Geophys. Res., 112, D02204, doi:10.1029/2005JD006832, 2007.

$20 \mathrm{Hu}$, R.-M., Carslaw, K. S., Hostetler, C., Poole, L. R., Luo, B., Peter, T., Fueglistaler, S., McGee, T. J. and Burris, J. F.: Microphysical properties of wave polar stratospheric clouds retrieved from lidar measurements during SOLVE/THESEO 2000, J. Geophys. Res., 107, 8294, doi:10.1029/2001JD001125, 2002.

Kaufman, Y. J., Tanre, D., Remer, L. A., Vermote, E. F., Chu, A. and Holben, B. N.: Operational 25 remote sensing of tropospheric aerosol over land from EOS moderate resolution imaging spectroradiometer, J. Geophys. Res., 102, 17 051-17 067, 1997.

Kaufman, Y. J., Tanre, D., and Boucher, A: satellite view of aerosols in the climate system, Nature, 419, 215-223, 2002.

King, M. D., Kaufman, Y. J., Menzel, W. P., and Tanre, D.: Remote sensing of cloud, aerosol and water vapor properties from moderate resolution imaging spectrometer (MODIS), IEEE Trans. Geosci. Remote.Sens., vol.30, 2-27, 1992.

King, M. D., Kaufman, Y. J., Tanre, D., and Nakajima, T.: Remote sensing of tropospheric

Oceanic impacts on ultraviolet radiance

R.-M. Hu and R. S. Sokhi

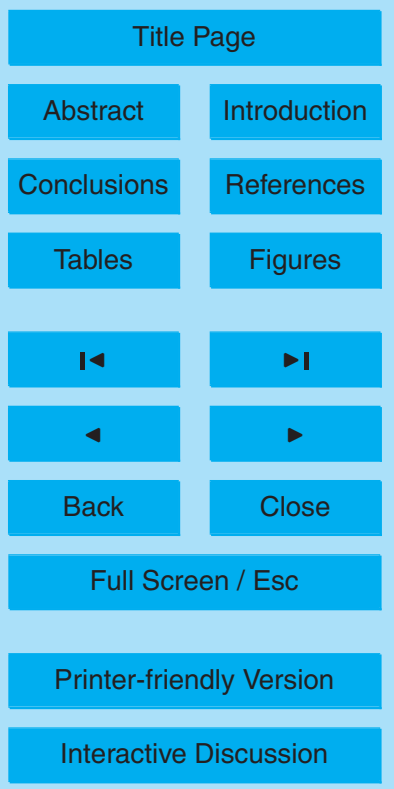

EGU 
aerosols from space: Past, present, and future, Bull. Am. Meteo. Soc., 80, 2229-2259, 1999.

Marshall, B. R., and Smith, R. C.: Raman scattering and in-water ocean optical properties, Appl. Opt., 29, 71-84, 1990.

5 Martin, R. V., Jacob, D. J., Logan, J. A., et al.: Interpretation of TOMS observations of tropospheric ozone with a global model and in-situ observations, J. Geophys. Res., 107, 4351, doi:10.1029/2001JD001480, 2002.

Martin, R. V., Jacob, D. J., Yantosca, R. M., Chin, M., and Ginoux, P.: Global and regional decreases in tropospheric oxide emissions constrained by space-based observations of $\mathrm{NO}_{2}$ columns, J. Geophys. Res., 108, 4097, doi:10.1029/2002JD002622, 2003.

Morel, A. and Maritorena, A.: Bio-optical properties of oceanic waters: A reappraisal, J. Geophys. Res.106, 7163-7180, 2001.

Natraj, V., Spurr, R., Boesch, H., Jiang, Y., and Yung,,Y.: Evaluation of errors in neglecting polarization in the forward modeling of $\mathrm{O}_{2}$ a band measurements from space, with relevance to $\mathrm{CO}_{2}$ column retrieval from polarization sensitive instruments, J. Quant. Spectrosc. Radiat. Transfe, 103(2), 245-259, 2006.

Park, R. J., Jacob, D. J., Chin, M., and Martin, R. V.: Sources of carbonaceous aerosols over the United States and implications for natural visibility conditions, J. Geophys. Res., 108, 4355, doi:10.1029/2002JD003190, 2003.

20 Park, Y.-J. and Ruddick, K.: Model of remote-sensing reflectance including bidirectional effects for case 1 and case 2 waters, Appl. Opt., 44, 1236-1249, 2005.

Platt, T., H. Bouman, E. Devred, C. Fuentes-Yaco, and S. Sathyendranath: Physical forcing and phytoplankton distributions, Scientia Marina, 69, 55-73, 2005.

Pope, R. M. and E. S. Fry: Absorption spectrum $(380700 \mathrm{~nm})$ of pure water. II. Integrating cavity measurements, Appl. Opt., 36, 8710-8723, 1997.

Quickenden, T. I. and Irvin, J. A.: The ultraviolet absorption spectrum of liquid water, J. Chem. Phys., 72, 4416-4428, 1980.

Spurr, R. J. D., Kurosu, T. P., and Chance, K. V.: A linearized discrete ordinate radiative transfer model for atmospheric remote sensing retrieval, J. Quant. Spectrosc. Rad. Trans., 68, 689735, 2001.

Sathyendranath, S. and T. Platt: Ocean-color model incorporating transspectral processes, Appl. Opt., 37, 2216-2227, 1998.

Torres, O., Bhartia, P. K., Herman, J. R., Ahmad, Z., and Gleason, J.: Derivation of aerosol

Oceanic impacts on ultraviolet radiance

R.-M. Hu and R. S. Sokhi

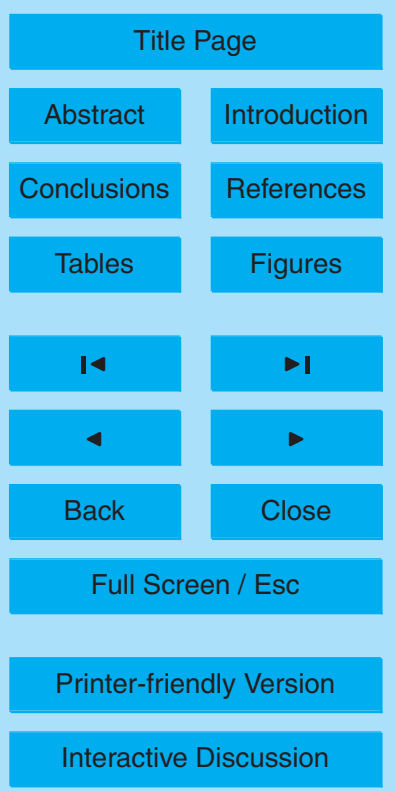

EGU 
properties from satellite measurements of backscattered ultraviolet radiation - theoretical basis, J. Geophys. Res., 103, 17 099-17110, 1998.

Vasilkov, A. P., Herman J. R., Krotkov N. A., et al.: Problems in assessment of the ultraviolet penetration into natural waters from space-based measurements, Opt. Eng., 41(12), 30193027, 2002.

Vasilkov, A. P., Herman J. R., Ahmad, Z., et al.: Assessment of the ultraviolet radiation field in ocean waters from space-based measurements and full radiative-transfer calculations, Appl. Opt. 44, 2863-2869, 2005.

\section{ACPD}

$7,14351-14367,2007$

Oceanic impacts on ultraviolet radiance

R.-M. Hu and R. S. Sokhi

Title Page

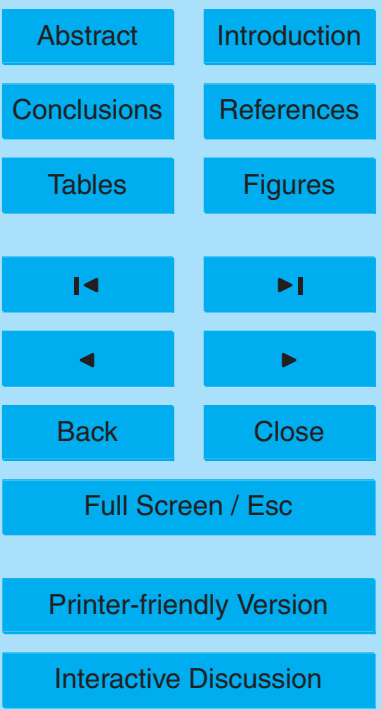




\section{ACPD}

7, 14351-14367, 2007

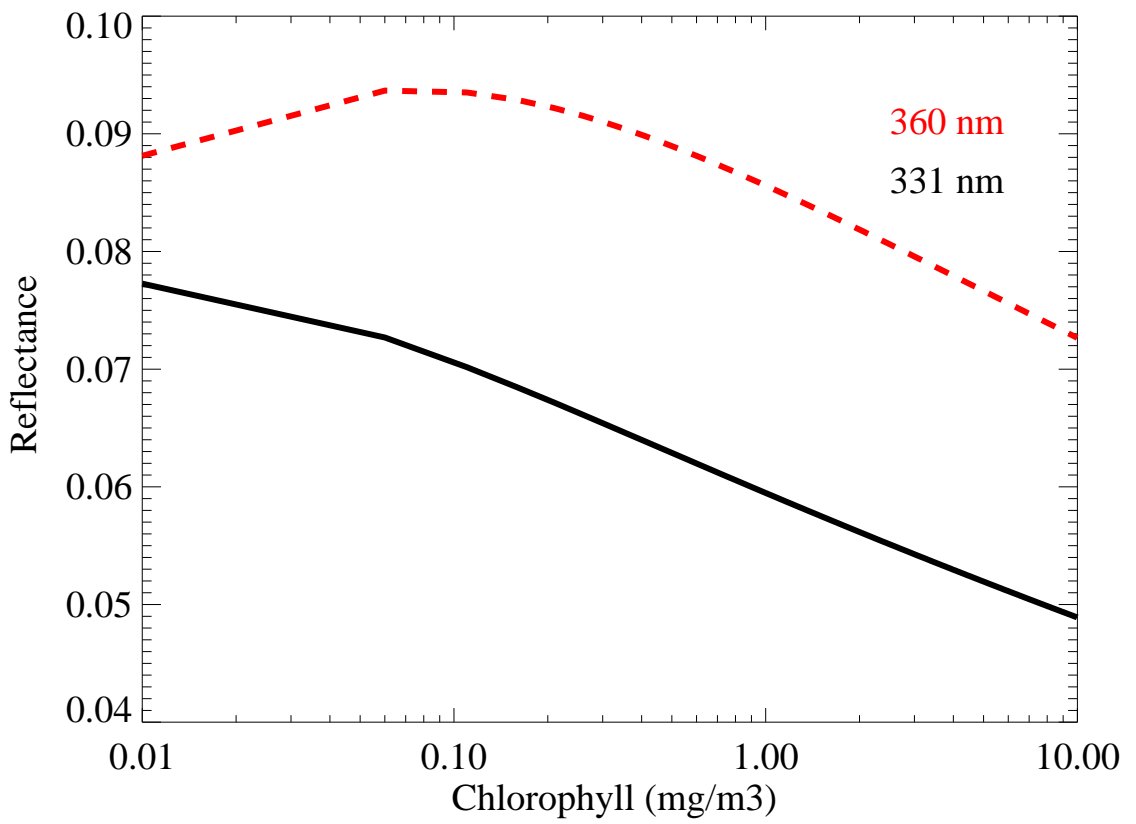

Oceanic impacts on ultraviolet radiance

R.-M. Hu and R. S. Sokhi

Title Page

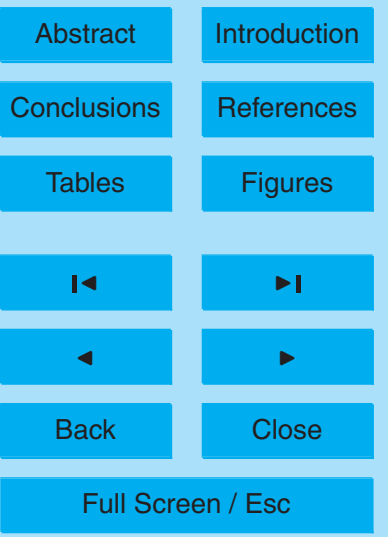

Fig. 1. The water reflectivity dependence on Chlorophyll concentration (without Raman scat-

Printer-friendly Version tering). 


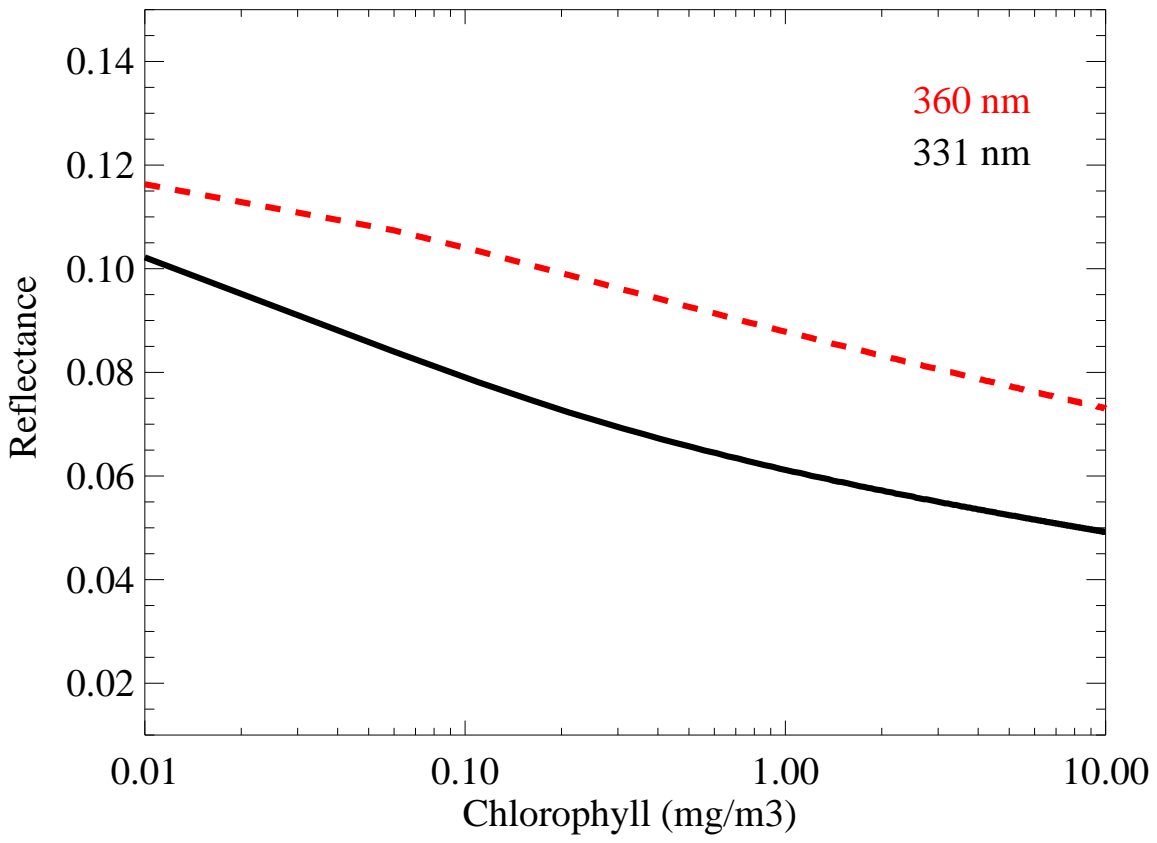

Fig. 2. The water reflectivity dependence on Chlorophyll concentration (with Raman scattering).

\section{ACPD}

$7,14351-14367,2007$

Oceanic impacts on ultraviolet radiance

R.-M. Hu and R. S. Sokhi

Title Page

\begin{tabular}{|c|c|}
\hline Abstract & Introduction \\
\hline Conclusions & References \\
\hline Tables & Figures \\
\hline I4 & \\
\hline 4 & \\
\hline Back & Close \\
\hline Full Screen / Esc
\end{tabular}

Printer-friendly Version

Interactive Discussion 


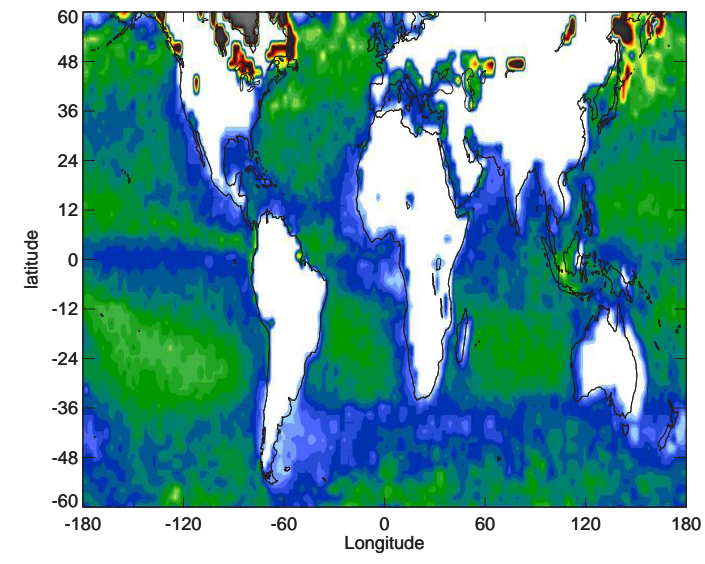

\section{ACPD}

7, 14351-14367, 2007

\section{Oceanic impacts on ultraviolet radiance}

R.-M. Hu and R. S. Sokhi
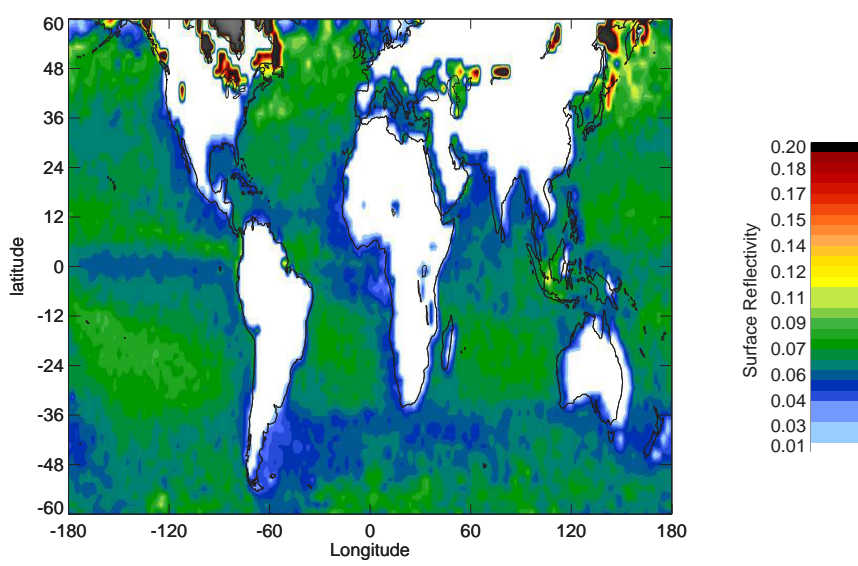

Title Page

Abstract

Conclusions

Tables

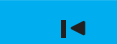

14

4

Back Introduction

References

Figures

I

$>$

Close

Full Screen / Esc

Printer-friendly Version

Interactive Discussion

Fig. 3. The surface reflectivity at $360 \mathrm{~nm}$. Upper panel is the observations from Herman et al. (1997), and lower panel shows the calculations with waters model. 


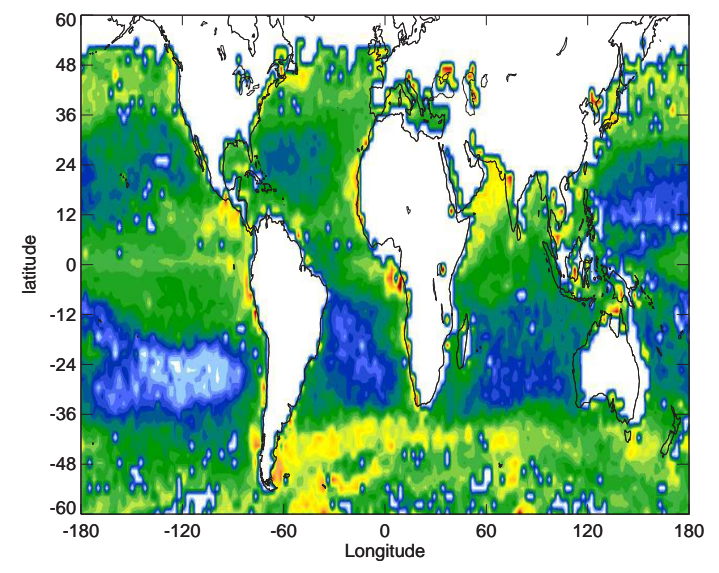

\section{ACPD}

7, 14351-14367, 2007

\section{Oceanic impacts on ultraviolet radiance}

R.-M. Hu and R. S. Sokhi
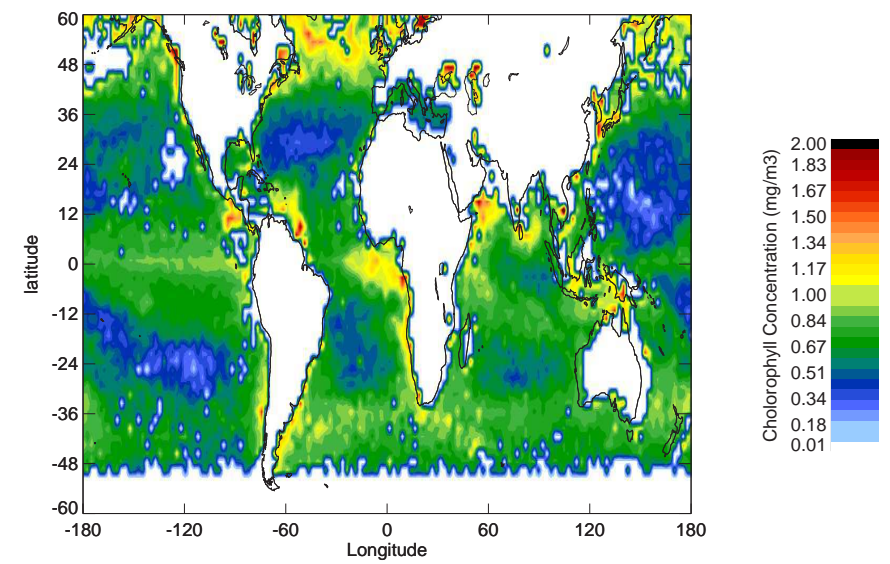

Title Page

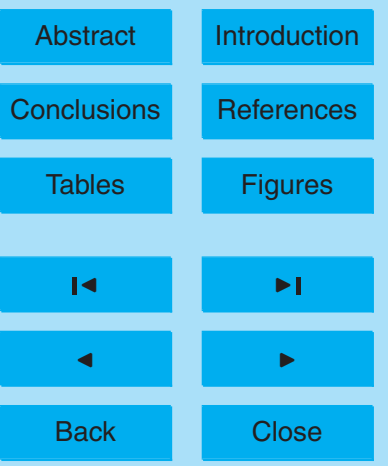

Full Screen / Esc

Printer-friendly Version

Interactive Discussion 

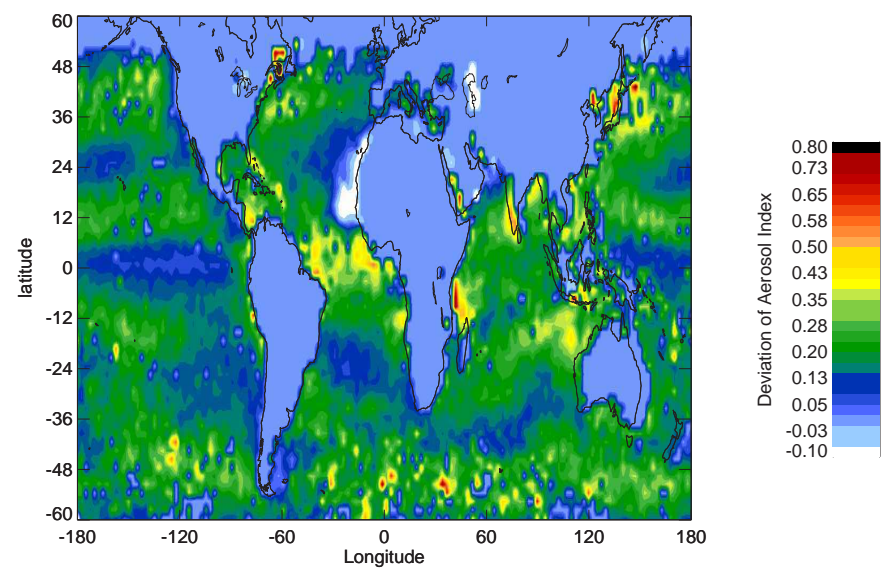

\section{Oceanic impacts on} ultraviolet radiance

R.-M. Hu and R. S. Sokhi
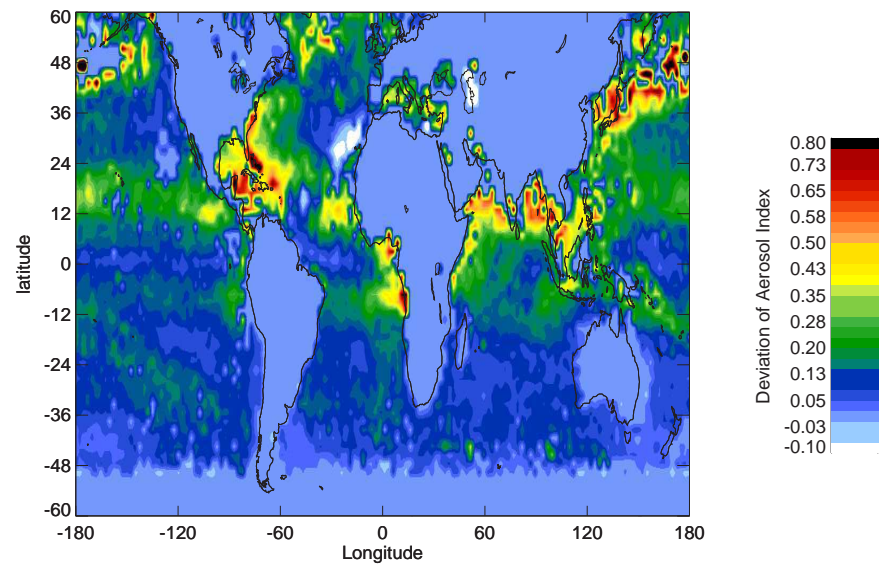

Title Page

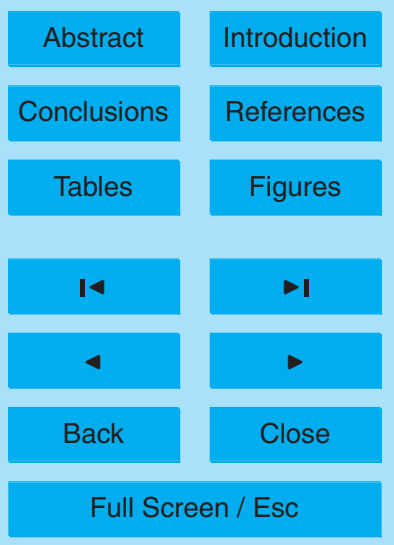

Printer-friendly Version

Interactive Discussion

Fig. 5. The difference between TOMS Aerosol Index calculated using the water reflectivity influenced by chlorophyll and the Lambertian water surface reflectivity. Upper panel is for January 2001 and lower panel is for July 2000. 

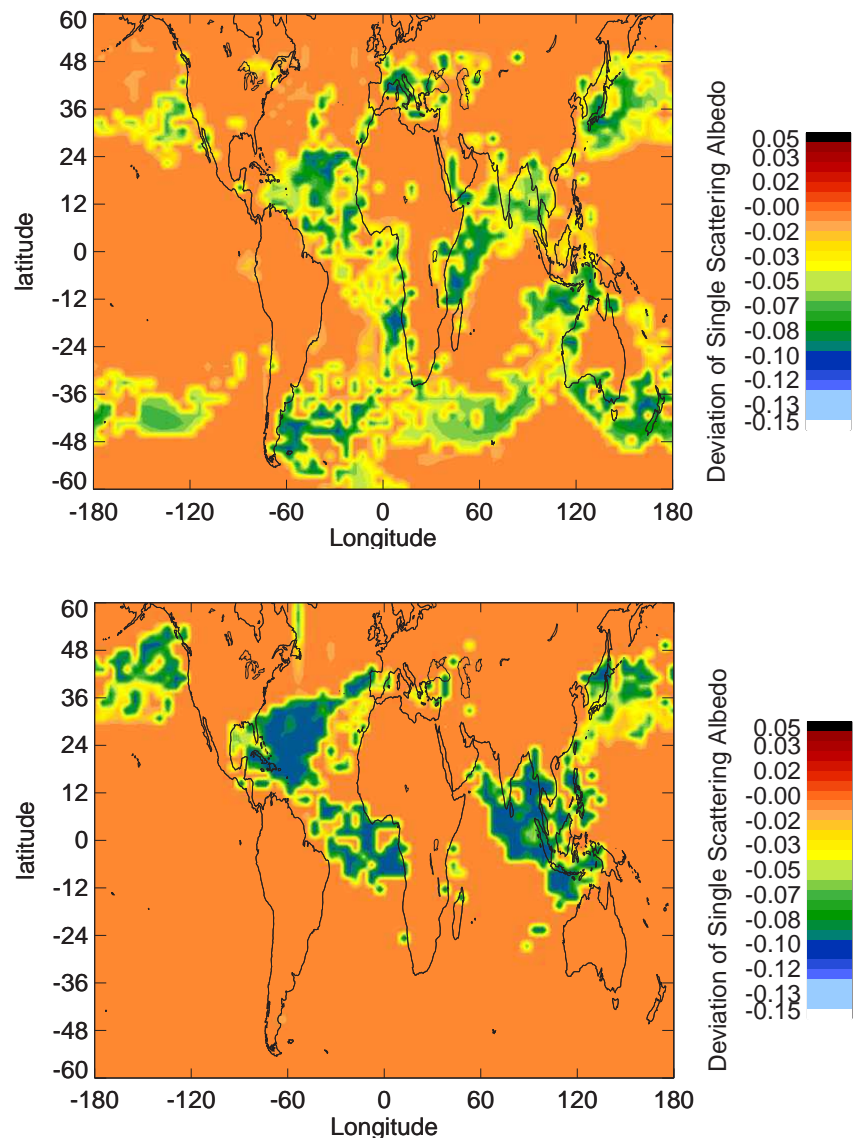

Oceanic impacts on ultraviolet radiance

R.-M. Hu and R. S. Sokhi

Title Page

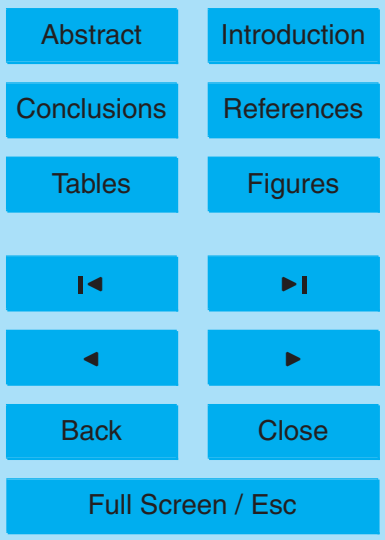

Printer-friendly Version

Interactive Discussion

Fig. 6. The difference between aerosol single scattering albedo retrieved with and withouout considering influence of Chlorophyll. Upper panel is for January 2001 and lower panel is for July 2000 . 